HStud 24 (2010) 1, 99-126

DOI: 10.1556/HStud.24.2010.1.5

\title{
TRANSITION TOWARDS SUSTAINABILITY: MYTH OR REALITY IN CENTRAL AND EASTERN EUROPE
}

\author{
ISTVÁN POMÁZI \\ Ministry of Environment and Water, Budapest \\ Hungary
}

\begin{abstract}
Twenty years after the fall of the Berlin Wall and five years after the biggest EU enlargement it is worth taking stock of the experiences of transition in Central and Eastern European countries in the context of sustainable development. The following article focuses on the principal economic, social, environmental, and institutional aspects of sustainable development in Central Europe, in particular in Hungary. The key challenges in the region are shared: how to respond to global financial and economic crises while avoiding deep social tensions and protecting the environment for future generations.
\end{abstract}

Keywords: transition, EU enlargement, sustainable development, environment, Central Europe, Hungary

Many studies have been devoted to analyses of the transition to market economy and democratic society in the context of environment quality and sustainable development. Rather than attempt to offer any kind of comprehensive assessments of the available literature, the following article focuses on the principal trends in economic, social, and environmental progress in Central and Eastern Europe, in particular in Hungary.

Of the recent publications on the subject, the book edited by Bochniarz and Cohen is particularly worthy of mention (Bochniarz and Cohen, 2008). In the study written by Archibald and Bochniarz the authors investigated sustainability issues in Central European countries using a wide range of statistical data and empirical knowledge, focusing primarily on the period between 1990 and 1996. They argued that the rapid liberalization of these countries was one of the major sources of the significant improvement in economic, social, and environmental performance (Archibald and Bochniarz, 2008). 


\section{EU Enlargement}

Twelve countries from Central and Eastern Europe and the Mediterranean joined the European Union in two waves, the first in 2004 (ten countries with 75,000,000 citizens) and the second in 2007 (two countries with 30,000,000 citizens).

The latest enlargements of the European Union have brought greater economic prosperity for all EU citizens and made Europe a stronger player in the world economy. The enlargement helped further unleash the growth potential and increase the resilience of the European economy by deepening economic integration and boosting competitiveness. The enlarged EU is now the largest integrated economic area in the world, accounting for more than $30 \%$ of the world's GDP and more than $17 \%$ of world trade (European Commission, 2009).

Rapid integration has brought many benefits for growth, but it also created vulnerabilities in some of the new member states that have been further accentuated by the current economic and financial crisis.

Foreign investment in the new member states surged quickly and boosted economic restructuring, growth, and employment. However, in several countries, rapid and unchecked domestic credit growth, fuelled by foreign borrowing, overheated the economy and led to large external imbalances, sharp increases in labor costs outstripping increases in productivity, and hikes in real estate prices. As a result, in some countries foreign capital was increasingly channeled to non-productive uses. With the large increase in the cost of capital brought about by the global financial crisis, countries with large external imbalances now face major adjustment challenges. These challenges, however, are not unique to new member states; some of the old member states face similar problems.

The enlarged EU is now better positioned to address current and future challenges. The reformed Stability and Growth Pact provides a medium-term anchor that underpins the credibility of fiscal policy, while allowing sufficient flexibility in the short run. In parallel, the revamped Lisbon process helps identify and focus on the structural reforms that are necessary to further enhance growth potential and resilience. This process has been supported by the Cohesion Policy, which translated Lisbon objectives into regional catch-up and development strategies. The Cohesion Policy provided substantial support to EU member states, both in terms of vital financial assistance and much needed expertise. The accession process has significantly improved living standards in the new member states, fostering economic and social cohesion within the Union. Income per capita rose from $40 \%$ of the old member states' average in 1999 to $52 \%$ in 2008 . It is estimated that the accession process boosted economic growth in the new member states by about $1.75 \%$ per year over 2000-2008, when growth increased from $3.5 \%$, on average, in 1999-2003 to 5.5 $\frac{1}{2} \%$ in 2004-2008 (European Commission, 2009). 
Rapid trade integration has fostered a more efficient division of labor and strengthened competitiveness in the EU. The degree of trade openness in the new member states has reached a very high level. Their average GDP share of exports and imports now amounts to $56 \%$ of GDP, up from $47 \%$ before enlargement.

New member states have been rapidly modernizing their economies. They have developed functioning market economies and the capacity to cope with competitive pressures and market forces within the single market. They have also increasingly aligned their production structures with those of the old member states. Agriculture and manufacturing are more important in the new member states (amounting to $4.5 \%$ and $21.25 \%$ of GDP respectively in 2006, compared with $1.5 \%$ and $16.75 \%$ in the old member states). Nonetheless, the service-based and knowledge-intensive economy has grown in recent years. The share of services in GDP grew from $56 \%$ of GDP in 1995 to $63 \%$ in 2006 , compared to $72 \%$ of GDP in the old member states. Investments from old member states have been a key driver of economic transformation in the new member states.

Foreign investment was particularly high in the financial sector. As a result, foreign ownership in the banking sector in the new member states now ranges from almost $100 \%$ in Estonia and Slovakia to some 30\% in Slovenia (compared with below $20 \%$ on average in the Euro area).

The current severe global economic crisis poses major new challenges for national policies. The crisis impacts all member states through declining trade, reduced availability of financing, plummeting household wealth and deteriorating confidence, though EU membership, and to a greater extent membership in the Euro zone, provides protection and a stability anchor.

The financial crisis has also exposed other vulnerabilities. In several new member states over-optimistic expectations about enterprise profits and household income fuelled capital inflows and credit growth that surpassed sound equilibrium levels. In many cases, this led to unsustainably high current account deficits. Foreign currency denominated loans have also expanded markedly in several countries. This has made households and corporations more vulnerable to currency depreciation.

These recent events underscore the fact that in all new member states further major efforts are needed to safeguard the achievements of the latest EU enlargements, particularly regarding income convergence, financial integration, and foreign direct investment into converging member states. The EU's policy frameworks are helpful in facing these challenges, and enable the new member states to continue to inject dynamism into their economies in the medium and long run. However, the results will mainly depend on sound domestic economic policies and an appropriate institutional framework. The implementation of cohesion policy and the EU's rural development policy, focused on long-term objectives, helps create conditions for sustainable growth. 
Total transfers from the EU budget to the new member states amounted to around 2\% of their GDP in 2007 and are expected to increase to 3\% by 2013 (European Commission, 2009). There were huge regional disparities in the European Union on the basis of GDP per inhabitant. In 2006 GDP per capita ranged from $25 \%$ of the EU-27 average in Nord-Est in Romania (Nord-Est is a term used to refer to a development region in the largely agricultural north-eastern part of the country) to $336 \%$ in inner London. Despite the convergence of new member states towards the EU average, there are nonetheless significant inequalities in economic topography.

The European Economic Recovery Plan adopted by the European Council in December 2008 proposes a counter-cyclical macro-economic response to the crisis in the form of an ambitious set of actions to support the real economy. The aim is to avoid a deep recession. The plan is anchored in the Stability and Growth Pact and the Lisbon Strategy for Growth and Jobs.

The strategic aims of the Recovery Plan are to:

- Swiftly stimulate demand and boost consumer confidence;

- Lessen the human cost of the economic downturn and its impact on the most vulnerable. Many workers and their families are or will be hit by the crisis. Action can be taken to help stem the loss of jobs; and then to help people return rapidly to the labor market, rather than face long-term unemployment;

- Help Europe prepare to take advantage when growth returns so that the European economy is in tune with the demands of competitiveness and the needs of the future, as outlined in the Lisbon Strategy for Growth and Jobs. This means pursuing the necessary structural reforms, supporting innovation, and building a knowledge economy;

- Accelerate the shift towards a low carbon economy. This will leave Europe well placed to apply its strategy for limiting climate change and promoting energy security: a strategy which will encourage new technologies, create new 'green-collar' jobs and open up new opportunities in fast growing world markets, keep energy bills for citizens and businesses in check, and reduce Europe's dependence on foreign energy.

An immediate budgetary impulse has been made amounting to 200 billion Euros (1.5\% of EU GDP), made up of a budgetary expansion by member states of 170 billion Euros (around 1.2\% of EU GDP) and EU funding in support of immediate actions of the order of 30 billion Euros (around $0.3 \%$ of EU GDP). An additional 105 billion Euros for "green economy" between 2007-2013, including renewable energy sources, energy efficiency, railways, clean urban transport development, is expected to be spent (European Commission, 2008). 


\section{Recent Economic Development in the EU-10 Region}

The deepest global recession since World War II has clouded the economic outlook in the EU-10 region (the EU-10 refers to Bulgaria, the Czech Republic, Estonia, Hungary, Latvia, Lithuania, Poland, Romania, the Slovak Republic and Slovenia). The EU-10 economies grew only modestly in the fourth quarter of 2008 (by 1\%), and are likely to have contracted in the first quarter of 2009. EU-10 countries are projected to contract by around 3\% in 2009 and reach $0 \%$ growth in 2010, down from growth rates of $4.1 \%$ in 2008 and $6.2 \%$ in 2007 . The collapse in export demand and the global deleveraging have resulted in a sharp economic downturn. Deep trade and financial integration with the rest of the world, and especially the Euro area, makes the region highly vulnerable to the reduction in external financing and the contraction in manufacturing exports (World Bank, 2009).

Economic activity is expected to contract in 2009 in all EU-10 countries and to recover only modestly, and only in some countries, in 2010. The Baltic countries are expected to suffer the most severe contraction. In the first quarter of 2009, the year-on-year reduction in GDP ranged from $18 \%$ in Latvia and $16 \%$ in Estonia to $3.5 \%$ in Bulgaria and 3.4\% in the Czech Republic.

Manufacturing plummeted in the fourth quarter of 2008 and the first months of 2009 , as sales of investment goods and consumer durables collapsed. In early 2009 , industrial production contracted year-on-year between $20 \%$ and $30 \%$ in Estonia, Latvia, Hungary, the Slovak Republic and the Czech Republic, a shock comparable only to the sharp slump of the early 1990s. Stocks of inventory, which had increased at the onset of the crisis, are now being slashed. The export-oriented manufacturing sector, in particular machinery, automobile, transport and electric equipment, but also the labor intensive industries, such as textiles and clothing, have been affected the most (World Bank, 2009).

The deterioration in the labor markets is closely linked to the downturn in economic activity. Estonia, Latvia and Lithuania are expected to see large increases in unemployment in the wake of the substantial contraction in the economy. Unemployment rates in these countries more than doubled relative to the same period of 2007, reaching levels that are among the highest in the EU. Employment growth was negative in Hungary and the Baltic states in the last quarter of 2008. Unemployment is also rising in the other countries of the region, and is likely to exceed $10 \%$ of the labor force in the Slovak Republic, Hungary and Poland by 2010. Return migration of the over 1,000,000 EU-10 citizens who moved to crisis-hit countries such as the UK, Ireland, and Spain since 2004 is adding further pressure to domestic labor markets (World Bank, 2009). 


\section{Main Socioeconomic and Environmental Trends in Wider Europe}

The pan-European region harbors rich cultural and environmental diversity. More than 870,000,000 people live in the region, more than half of them in Western and Central Europe (WCE), making the EU one of the most densely populated areas of the world, with more than 100 people per square kilometer. This is in stark contrast to the relatively sparse populations of Eastern Europe and Central Asia, where the average density is well below 20 people per square kilometer.

Economic recovery in recent years has resulted in an increase, in relative terms, of national income in virtually all countries of the pan-European region. Economic growth rates have been particularly high in South Eastern Europe (SEE) and EECCA (Eastern Europe, Caucasus and Central Asia) countries. The number of independent states in the region has increased from 33 in 1990 to 53 in 2007, during which time the EU expanded from 15 to 27 member states.

Air pollution, mainly by fine particles and ground-level ozone, continues to pose a significant threat to health. It shortens average life expectancy in WCE by almost one year and affects the healthy development of children. Most air pollutants have increased in EECCA by more than $10 \%$ as a result of economic recovery, increases in transport, and the lack of effective air pollution protection policies. In EECCA the poor quality of the data precludes an in-depth assessment of air quality and its consequences. However, the limited data available indicates that the main health threat in EECCA and SEE is, as in WCE, from small particles and their toxic constituents (EEA, 2007).

More than 100,000,000 people in the pan-European region still do not have access to safe drinking water and adequate sanitation. In EECCA and SEE the quality of the water supply and sanitation services has deteriorated continuously over the past 15 years, with the rural population most affected. One-third of the pan-European population lives in countries where water resources are under substantial pressure. High leakage losses in water distribution systems, poor management and maintenance of irrigation systems, and unsustainable cropping patterns exacerbate the impacts of droughts and water scarcity.

Emissions of greenhouse gases have increased in recent years in most European countries and are projected to continue to do so in the future. Many European countries have adopted national programs to reduce emissions, but some of them will still have difficulties in reaching their Kyoto targets. The Kyoto Protocol, under the UN Framework Convention on Climate Change, and its first commitment period represent only a first step in addressing climate change. Global emissions will have to be reduced by up to $50 \%$ by 2050 to limit temperature increases to a maximum of $2{ }^{\circ} \mathrm{C}$ above pre-industrial levels, the target proposed by the $\mathrm{EU}$ as necessary to avoid unacceptable climate change impacts in the future. 
Biodiversity decline and loss of ecosystem services continue to be a major concern across the pan-European region. In addition, the number of invasive alien species in the region continues to increase. The overarching target of the Kiev Resolution to halt biodiversity loss in the region by 2010 will not be achieved without considerable additional efforts and resources. Communication, education and public awareness programs, however, are being implemented according to the Kiev Resolution. There has been significant progress in creating ecological networks: the Pan-European Ecological Network and Natura 2000 Network are taking shape, but there is still insufficient information on their conservation status (EEA, 2007).

The concept of sustainable consumption and production has become more prominent on the policy agenda since the Kiev Conference. However, few concrete outcomes have emerged, and implementation strategies and tools to measure environmental impacts need to be put in place. Per capita resource use levels have remained stable in all regions over recent years, and some decoupling has been achieved between resource use and economic growth. Resource use efficiency varies significantly between countries, and is several times higher in the EU-15 than in the EU-10 and SEE countries, and up to twenty times higher than in EECCA. Patterns of consumption are changing rapidly, driven by socioeconomic changes. The consumption categories causing the highest life-cycle environmental impacts are food and beverages, private transport, and housing. In the EU, tourism and air travel are emerging as key areas of future impacts.

The pan-European region is generating ever more waste. Landfill, environmentally the least preferred option, is still the most common method of waste management across the pan-European region. EU member states have made some progress in limiting the share of municipal waste going to landfill. Many EECCA and SEE countries have developed waste strategies and legislation for waste, but they still need to be implemented effectively. Proper waste collection and safe landfilling remain a challenge. In some EECCA countries an even bigger challenge is ensuring the environmental safety and cleanup of hazardous waste sites inherited from the past (EEA, 2007).

\section{Recent Economic and Social Trends in Hungary}

Between 1995 and 2006 the Hungarian economy showed an uneven trend influenced by changing external and internal economic and social conditions. Since the change of regime the economy has become more open, while in key sectors productivity and competitiveness have improved. These developments were supported by several factors, such as modern technical improvement, changes in the 
structure of production, better logistics, and last but not least increasing labor intensity.

In the period starting in 1997 , for the first time since the change of regime the dynamic economic growth was not followed by a dangerous deterioration of the external balance of payments. As a consequence of the package of measures introduced in 1995 (one-time currency depreciation, introduction of an import surcharge, measures restricting demand) the indicators of equilibrium improved spectacularly, but at the same time economic growth temporarily slowed down.

Subsequently, as of 1997 the volume index of GDP rose dynamically, peaking at $5.2 \%$ in 2000 . In this period industry and construction were the engines of growth. From 2001 the growth rate declined. The reasons for this were the deterioration of external economic conditions and the worldwide spread of poor business performance, which was followed by significantly lower export growth rates than in previous years. In 2004, when Hungary joined the EU, a business recovery occurred again, which played a key role in GDP growth rate, which reached $4.8 \%$. The spectacular improvement was due to the improved agricultural output on the production side and the dynamic increase of exports and investments on the expenditure side. In the next two years, in 2005 and 2006, the growth rate declined again, and the driving force in these years essentially was the above-average increase of three branches: manufacturing, wholesale and retail trade and repair, and financial intermediation.

The consolidated gross debt of the general government is one of the criteria of the Maastricht Treaty that has to be met in order to enter the Euro area. According to the Treaty, the gross government debt must not exceed $60 \%$ of the gross domestic product (GDP), or it has to decrease and approach the threshold to a sufficient extent and at a sufficient rate. This is a requirement of long-term sustainability of government. In Hungary government debt decreased gradually and substantially in the second half of the 1990s, reaching the lowest point in 2001, which was far below the $60 \%$ threshold. Government debt has been increasing ever since. It exceeded the limit again in 2005 and was the fourth highest within the 27 EU member states in 2007, when it surpassed the value recorded 10 years before. In the European Union the average government debt fluctuated between $61 \%$ and $63 \%$ in the first six years of the decade, but decreased substantially and fell below the $60 \%$ threshold in 2007.

On the basis of per capita GDP in Hungary the differences in economic development of the regions increased in the period between 1995 and 2006. During this time central Hungary, western Transdanubia, and central Transdanubia took the first three places, and either northern Hungary or the northern Great Plain came in last. Over the period under examination GDP per capita increased at a higherthan-average rate in central Hungary and western Transdanubia. Central Transdanubia was close to the average level, while the other four regions fell behind by 
different measures. The variable of development was 2.05 and 2.63 times higher in central Hungary than in the northern Great Plain (the last region in the rankings) in 1995 and 2006, respectively. If the figures of central Hungary, due to its special position, are not taken into account, then the per capita GDP of western Transdanubia in 1995 was 1.45 times as high as that of the northern Great Plain, the least developed region. This indicator changed to 1.59 in 2006.

Hungary's GDP per capita was 14,393 purchasing power standards (PPS) in 2005 , which was 64.3 per cent of the EU-27 average. GDP per capita in central Hungary exceeded the EU average by $5 \%$, while in central and western Transdanubia these figures were $60-64 \%$ of the EU average. The situation of the other regions was much less favorable, since none of these regions reached half the EU average (41-45\%). In 2005 GDP per capita in PPS, as compared to the EU-27 average, was higher in Slovenia (86.9\%) and in the Czech Republic (76.6\%), among the countries of the area, than in Hungary. The figures for Estonia $(62.9 \%)$ and Slovakia (60.6\%) are not far from those of Hungary. The GDP per capita in Romania and Bulgaria, the two new member states, was equivalent to $35 \%$ (HCSO, 2008).

The renewed sustainable development strategy (EU SDS) aims to promote a prosperous, innovative, knowledge-rich, competitive, and eco-efficient economy. Energy intensity monitors how much energy is used in a country to produce one unit of economic output, and measures one aspect of eco-efficiency by identifying to what extent there is a decoupling between the growth rates of energy consumption and economic performance. Changes in energy intensity depend on energy efficiency, energy sources used and structural economic changes.

The average energy intensity of the EU-27 declined by almost 15\% from 1995 to 2006 , a figure very close to the EU-15 average (12.6\%). The fall in energy intensity of the Visegrád countries was $30 \%$ on average, yet even in 2006 the energy these countries required in order to achieve a unit of economic performance was significantly more than the EU average. Though the energy intensity of Hungary was nearly three times as high as in the EU-27 in 1995, the gap slightly diminished by 2006. It is worth noting that Poland nearly halved its lag behind the EU-27 from 1995 to 2006.

Mass unemployment appeared in Hungary after the transition at the beginning of the 1990s. It reached its highest level in 1993, when the unemployment rate was $12.1 \%$. The decline could be observed until 2001 (5.7\%), at which point it began to increase again, and since 2005 it has exceeded 7\% (HCSO, 2008).

The main objective of the new EU Sustainable Development Strategy (SDS) in the topic "Social integration, demography and migration" is to reduce the number of people, especially the number of children, at risk of poverty and social marginalization by 2010. In Hungary the national at-risk-of-poverty rate corresponds to the average of the EU-15 member states. While the EU average in- 
creased only slightly in the period under observation, the data reveals that though the situation in Hungary was good in $2000(11 \%)$, by 2005 the Hungarian indicator had come to equal the EU-15 average (16\%).

Examining the child poverty rate, one observes that it follows the trend of the national average, though it is consistently higher. As opposed to the increase in the national average from $11 \%$ to $16 \%$, the child poverty rate grew from $17 \%$ to $25 \%$, which means that one fourth of minors lived below the poverty threshold in 2005.

The indicator of the inequality of income distribution is the quotient of the equalized income of the top income quintile and that of the lowest income quintile. It is an important indicator of social inequalities, which is known also as S80/S20. The higher the value, the larger the inequalities.

According to the time series the income quintile share ratio has hardly changed in the 15 old Member states of the EU. It was around 4.5 every year, though there was a slight increase. In Hungary significant growth can be observed. The ratio grew from the 3.3-fold difference registered in 2000 to 5.5-fold by 2005 .

In Hungary life expectancy at age 65 was 13.4 years among males, and 17.2 years among females in 2006. The respective values of this indicator were 12.1 and 15.8 in 1995. In 2005 the average life expectancy at age 65 was 16.4 years for males and 20.3 years for females in the EU, in the case of both genders more than three years than in Hungary (HCSO, 2008).

In 2006 most deaths in Hungary were caused by diseases of the circulatory system, followed by neoplasms. These two causes resulted in more than $70 \%$ of the total number of deaths. Due to their relative significance, the number of deaths due to diseases of the digestive system, external causes, and diseases of the respiratory system should be stressed as well. These amount to $17 \%$ of the total number of deaths. Other causes amount to only $8 \%$ of the total number of deaths. The structure of causes of death is very similar for the two genders.

There is a difference in the proportions of the major causes. In 2006 the proportion of deaths due to neoplasms, diseases of the respiratory system, digestive system, and external causes were higher among men, while diseases of the circulatory system led to death more frequently in the case of women.

In order to draw international comparisons we use the WHO mortality rate, standardized for the European population. In all the five main groups of causes of death the standardized rates of Hungarian men are much higher than the EU average. In 2005 the rate of those dying from diseases of the digestive system was more than twice the EU average, while the rate was nearly twice the EU average in the case of deaths due to diseases of the circulatory system. In 1995 the number of deaths from suicide was 50 per hundred thousand for men and 17 per hundred thousand for women. Twelve years later this rate had decreased to 39 per hundred thousand among men and 11 per hundred thousand among women. The difference 
between genders did not change in the period under examination. More than $70 \%$ of those deceased due to suicide were men. Despite the decrease, Hungarian figures are still considered outstandingly high in an international context. In 2005 the EU average of deaths from suicide was 18 per hundred thousand for men and 5 per hundred thousand for women (HCSO, 2008).

Obesity is an increasingly significant problem in the developed world. Nearly half of the Hungarian adult population is overweight or obese. Data from the population health interview surveys suggests that the middle-aged and elderly are particularly likely to be overweight. More than two-thirds of the male population over age 45 is overweight, and this figure is only slightly lower in the case of women of the same age. In the three years between the two surveys (2000-03) there was a slight increase in the proportion of overweight people for both genders.

The average living standards, housing conditions, health status, employment, and schooling of the Hungarian Roma population are far below the Hungarian average. The income of $82 \%$ of this group is below the sustenance level. $56 \%$ of the members of the Roma community belong to the poorest $10 \%$ of the total Hungarian population. The rate of employment is less than half and the unemployment rate is $3-5$ times higher. $12 \%$ of the overall population and $19 \%$ of children $(420,000)$ live below a widely accepted poverty threshold. The basic document of the National Strategy 2007-32 "Making Things Better for our Children", adopted by the Parliament in May 2008, addresses the severe problem of child poverty in Hungary.

\section{Environmental Situation and Policy in Hungary}

Shifts in social and economic conditions in Hungary from the mid-1980s onwards and the effects of the regime change in 1989 curbed a hitherto intense environmental deterioration and put an end to severe contamination in a number of fields. As a result of this, decreasing environmental pressures have led to the improvement in the quality of the environment.

\section{Air Pollution}

In the 1980s a huge, contiguous strip of severely polluted air stretched along the north-east-south-west industrial axis, across the north Hungarian and Transdanubian mountains, enveloping the cities of Miskolc, Budapest and Veszprém to such an extent that air pollution endangered the health of nearly half of Hungary's population. Due to a decrease in the emission of air pollutants, areas with ex- 
tremely high levels of air pollution are now only found in small and scattered patches. Since 2000, the proportion of national territory with poor ambient air quality has fallen from $11 \%$ to $6.3 \%$, and the share of the population affected by air pollution has dropped from $40 \%$ to $35.9 \%$. The rate of improvement is best seen when comparing levels of sulfur dioxide emissions. In $1980 \mathrm{SO}_{2}$ emissions reached 1.633 million tons, whereas in 2006 only 118,000 tons were emitted, representing a 93\% reduction (Pomázi-Szabó, 2008a). The emission of nitrogen oxide decreased from 238,000 tons in 1990 to 208,000 tons in 2006, mainly due to the restructuring of the power sector (see Figure 1).

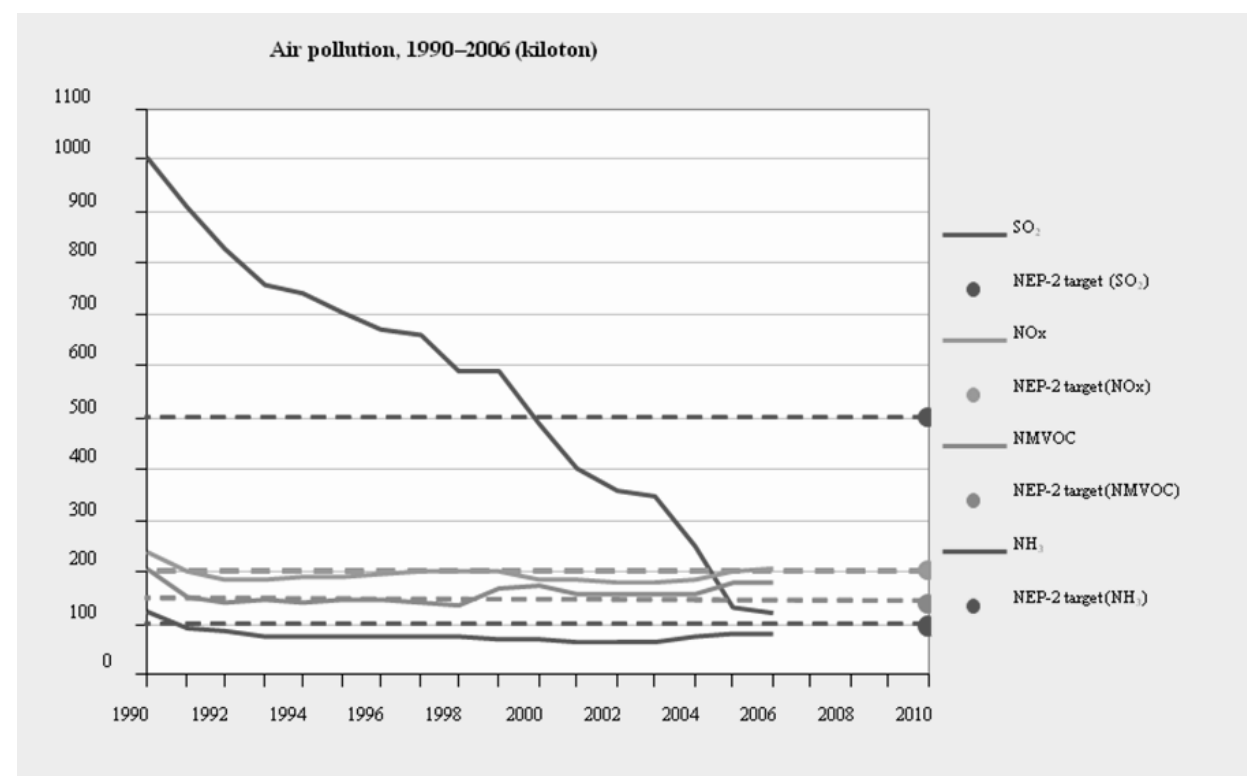

Figure 1. Air pollution

Source: Pomázi-Szabó (2008a).

Over the period between 1980 and 2006, emissions of particulate matter decreased from 576,600 tons to 83,000 tons (i.e., from 54 kilograms to 8 kilograms per capita). The most severely polluted mosaics were found in the vicinities of $\mathrm{Bu}$ dapest, Miskolc, Salgótarján, Pécs, and Szeged. Since the 1990s, air pollution from transport has begun to endanger settlements near motorways and major roads. Suspended particulate matter (PM) poses an extensive problem in Hungary. In 2007 the highest concentrations of PM were measured in cities such as Budapest, Miskolc, Pécs, Szeged, and Várpalota. High PM concentrations are mainly linked to heavy traffic, residential heating and, in some places, local indus- 
trial production. Background concentrations of $\mathrm{SO}_{2}$ have been considerably reduced following the trend in declining emissions. In 2007, $\mathrm{SO}_{2}$ emission limits were being respected throughout Hungary. Background concentrations of $\mathrm{NO}_{2}$ have been slightly reduced in recent years, but the annual average emission levels were exceeded in Budapest, Miskolc, and Pécs.

Ground-level ozone is a major concern throughout the country. In 2007 health protection standards were exceeded at all ozone monitoring stations. The highest rates of excess were recorded in Budapest, Dunaújváros, Kazincbarcika, Salgótarján, and Tatabánya.

Ragweed pollen (Ambrosia artemisiifolia) potentially affects Hungarians who suffer from respiratory diseases or allergies (see Figure 2). In 2004-05 the country's ragweed cover and airborne pollen levels generally dropped, but both increased again in 2006. In 2008 the highest daily concentrations of ragweed pollen (measured in pollen grains per cubic meter) were registered in Nyíregyháza $(1,015)$, followed by Szeged (976), Kecskemét (968), and Győr (957).

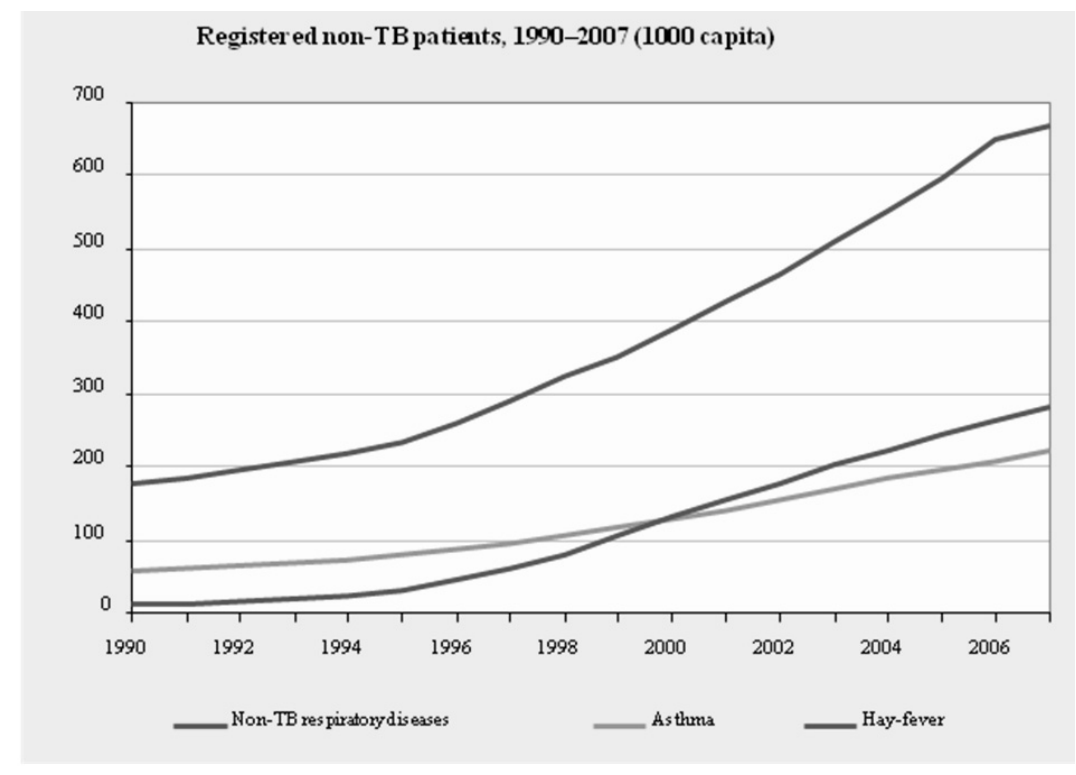

Figure 2. Environmental health

Source: Pomázi-Szabó (2008a).

With regards to climate change, the reduction in greenhouse gas emissions from 115.8 million tons in 1990 to 78.6 million tons in 2006 is notable $(-32 \%)$. The most significant reduction took place between 1988-1992 due to the collapse 
of energy intensive industries and the restructuring of the Hungarian economy (see Figure 3).

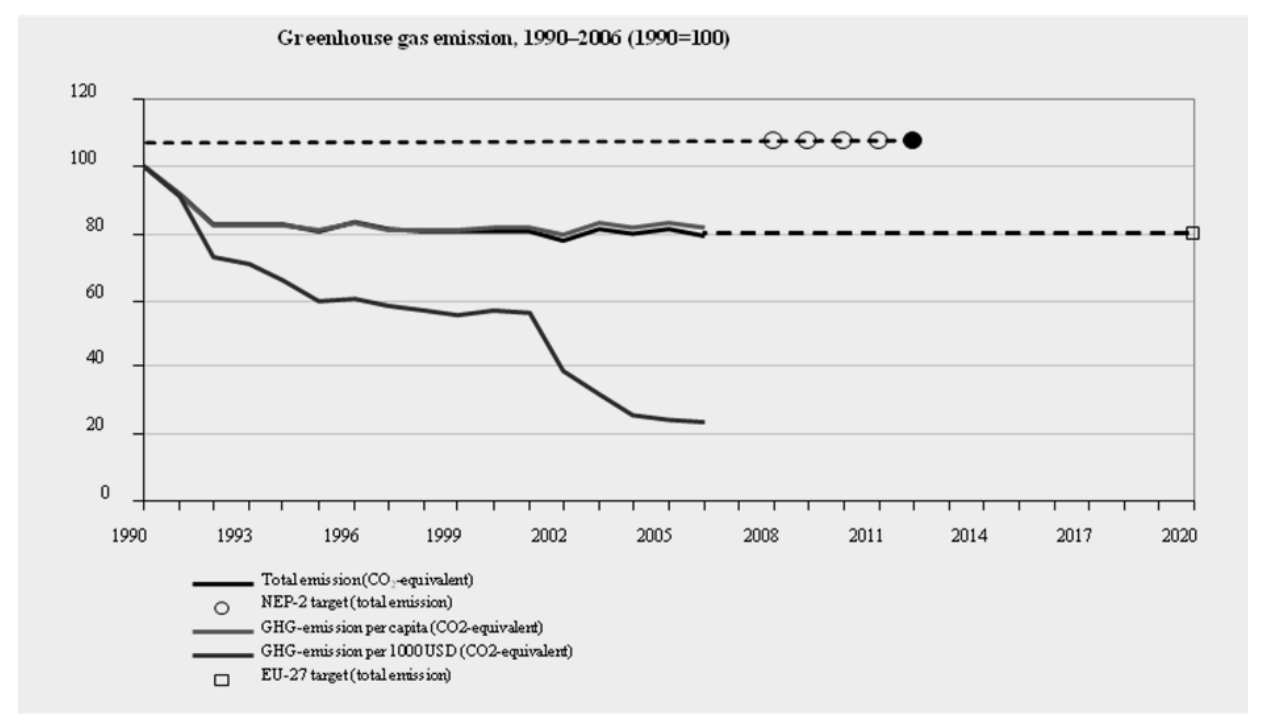

Figure 3. Greenhouse gas emission

Source: Pomázi-Szabó (2008a).

Such a considerable decrease has also come about as a result of changes in the energy generation mix (Pomázi-Szabó, 2008a). To meet future climate change challenges, the Hungarian Parliament unanimously adopted the National Climate Change Strategy in March 2008. Prior to 1990 seventeen coal-fired thermal power stations were in operation, whereas by 2008 only one remained that was exclusively coal-fired. Currently there are ten mixed-fuel power plants (using mostly natural gas, biomass and coal), four that operate on natural gas and oil, while two power plants were permanently decommissioned. Between 1998 and 2006, state expenditure for the purposes of landscape rehabilitation amounted to 20.52 billion HUF (approximately 8,000,000 EUR at current exchange rates), in the wake of terminating uranium ore mining in the Mecsek Mountains. The funding primarily covered tasks related to pollution abatement and clean-up of the site.

The natural environment suffered severely as a result of the activities of the armed forces prior to 1989. The former Soviet Army had completed their gradual withdrawal from military bases in Hungary by 1991. After their departure, 171 registered and abandoned military objects remained in the country, and Hungary 
spent around 5 billion HUF on pollution abatement, site clean-up and landscape rehabilitation in the period between 1994 and 2006.

\section{Water Pollution}

About $95 \%$ of Hungary's surface waters originate abroad, and the borders of the country are crossed by 24 incoming rivers, which bring 114 cubic kilometers of water annually. The risk of surface water pollution is still grave and widespread, especially by nutrients and hazardous substances. The Danube generally has good water quality with regard to chemical pollutants, whereas the Tisza is contaminated by mercury and zinc. Bacterial contamination still prevails in large rivers (e.g., the Danube and the Tisza). Some $60 \%$ of the Danube and $90 \%$ of the Tisza are accorded 'quality class IV' (polluted) for microbiological parameters, and about $80 \%$ of the Tisza's length is accorded qualities IV and V (extremely polluted) for micro-pollutants.

Groundwater accounts for only $16 \%$ of total water abstractions, but it provides almost the entire drinking water supply of the country ( $40 \%$ is bank-filtered, about $10 \%$ is shallow groundwater and the rest is held in deep aquifers). Shallow groundwater is mostly affected by nitrates originating from agriculture and untreated municipal wastewater.

A national river basin management plan is being prepared in order to implement the EU Water Framework Directive. Hungary is a country prone to inundation and has the largest flood protection system in Europe (more than 4,200 kilometers). In the last decade the country has taken significant steps towards reducing its vulnerability to flood hazards, including the preparation of flood prevention and mitigation plans and the revision of land use planning and local construction regulations.

Despite the progress made in extending the water supply and improving purification technology, $23 \%$ of the drinking water (supplying 900 settlements with 2.5 million inhabitants) does not comply with EU standards for ammonium, arsenic, nitrite, fluoride, boron, iron and manganese content. The volume of municipal liquid waste produced in settlements without sewerage systems totals 100,000,000 cubic meters annually. Approximately $95 \%$ of this seeps into the soil from poorly or incorrectly constructed septic tanks. Statistics reported 4,690,000 cubic meters of collected municipal liquid waste in 2007 . The regional distribution in the volumes of municipal liquid waste can be explained by the widening gap between the availability of piped drinking water and a sewerage system over the period between 1945 and 1995. The drinking water network was completed by the mid-1990s. By $200794.7 \%$ of dwellings were being supplied by piped water and $69.8 \%$ of them were connected to the sewerage network (see Figure 4). The 
amount of municipal liquid waste decreased during the period between 1990 and 2007 with the extension of the sewerage system, yet certain spatial disparities continue to exist (Pomázi-Szabó, 2008a).

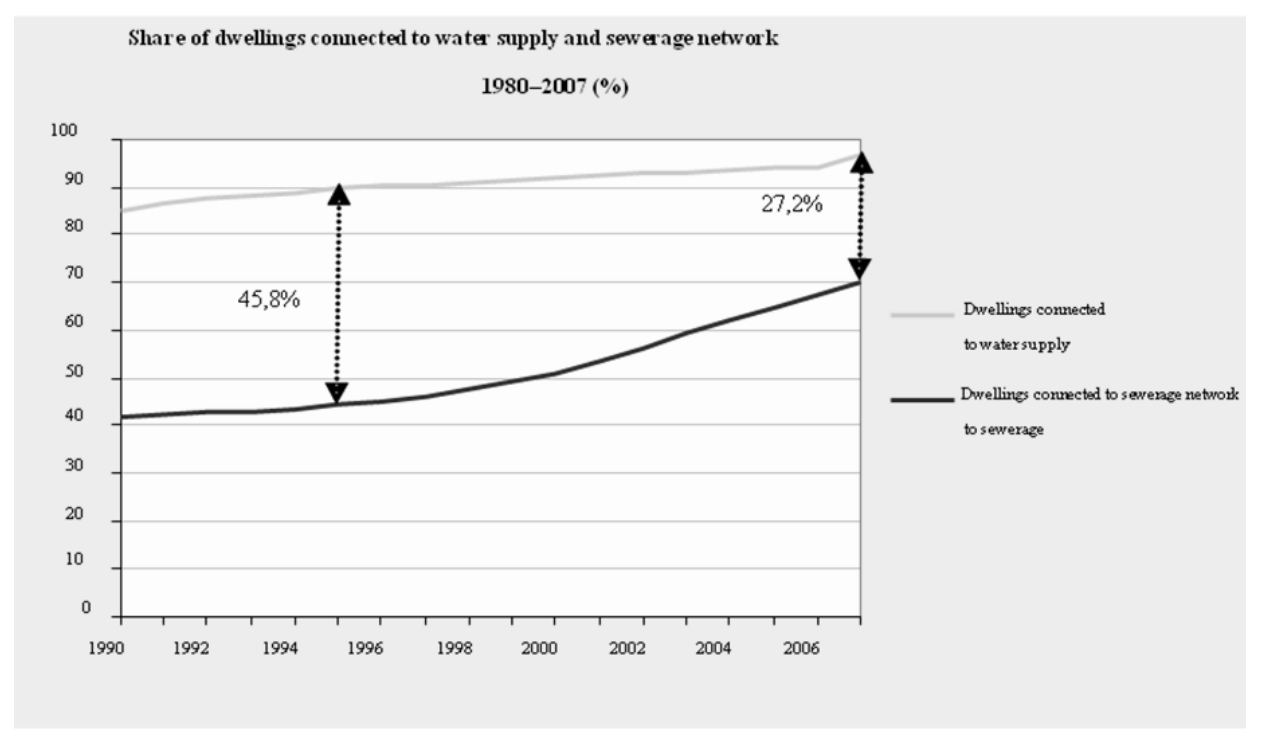

Figure 4. Water supply and sewerage

Source: Pomázi-Szabó (2008a).

Waste Management

Waste management bears a special significance as far as the quality of the environment is concerned, and in 1990 Hungary inherited severe problems in this field as well. The amount of waste being produced by industry and municipalities has been steadily decreasing since the 1980s. In 1990 this amount was 106,000,000 tons, deposited in approximately 2,700 legal landfills. There are no estimates available as to the number of illegal dumps. Due to economic restructuring, the total quantity of waste dropped to $90,000,000$ tons by 1995 and $68,700,000$ tons by 2000.

Industrial and commercial waste includes the waste material of various technologies and their by-products. Before 1989 the annual amount of waste from production activities reached 100,000,000 tons. By 1992 production waste totaled a yearly 80,000,000 tons, and by 1994 it had dropped to two-thirds of the 1989 quantity. Approximately 500,000,000 tons of industrial waste $(99 \%$ deriving 
from mining, iron ore smelting, steel manufacturing, electricity production, and construction) has been deposited in old landfills. These have been shut and are today mostly reclaimed. An estimated $7 \%$ of the waste deposited in landfills qualifies as hazardous, and $90 \%$ of it is red mud from alumina extraction, whereas the remaining $10 \%$ is drilling mud.

Present-day waste management is regulated by the Waste Management Act of 2000. The National Waste Management Plan (2003-08) sought to minimize the generation of waste, including hazardous waste. Today, of a total of $26,600,000$ tons of waste material, municipal waste accounts for $4,700,000$, and there are $1,360,000$ million tons of hazardous waste. Industrial and commercial waste amounts to $20,500,000$ tons and is properly treated.

The amount of collected municipal solid waste increased by $188 \%$ in the period between 1990 and 2006 (200.9 kilograms per person in 1990, rising to 455.3 kilograms per person in 2006), yet there are significant regional differences (see Figure 5). The increase can be attributed to economic restructuring and changes in the standard of living and consumer habits, as well as to the fact that most settlements (except for major cities) did not have organized refuse collection before 1990 (Pomázi-Szabó, 2008a). The annual amount of collected municipal solid waste is especially high (over 600 kilograms per person) in the counties of KomáromEsztergom, Veszprém, and Győr-Moson-Sopron. Such high quantities occur for a variety of reasons, including changing consumer habits and changes in heating systems, since central or gas heating does not facilitate the burning of otherwise combustible waste. In small settlements, however, municipal solid waste is handled locally, which is reflected in the low quantities for Békés or Bács-Kiskun counties. The composition of municipal solid waste shows that the nationwide constituents of waste largely mirror that of Budapest. In 2007 decomposing organic matter was the highest proportion of communal solid waste $(24.5 \%)$, followed by plastics (18.3\%) and paper (6.5\%). Metal and glass represent the lowest percentages. The total amount of recycled material maintains these proportions. In order to facilitate selective waste collection 4,000 recycling collection points and 74 waste collection yards are available in 500 settlements.

The quantity of hazardous waste has been gradually decreasing since the early 1990s due to industrial restructuring. The aluminum industry, one of the major sources of such waste, has dwindled significantly, thus the quantity of red mud as its residue has decreased too. Hazardous waste output has diminished by $49 \%$ in the period between 1996 and 2006. The most significant decrease occurred in Southern Transdanubia, as the amount of hazardous waste per person was nearly thirty times less in 2006 than in 1996. Major causes of the decrease include the closure of excessively polluting, large-scale industrial works, e.g. uranium mines and enrichment facilities, coal mines, tanneries, shoe factories and other chemical plants. Low values are typical of the Somogy and Tolna counties for similar rea- 


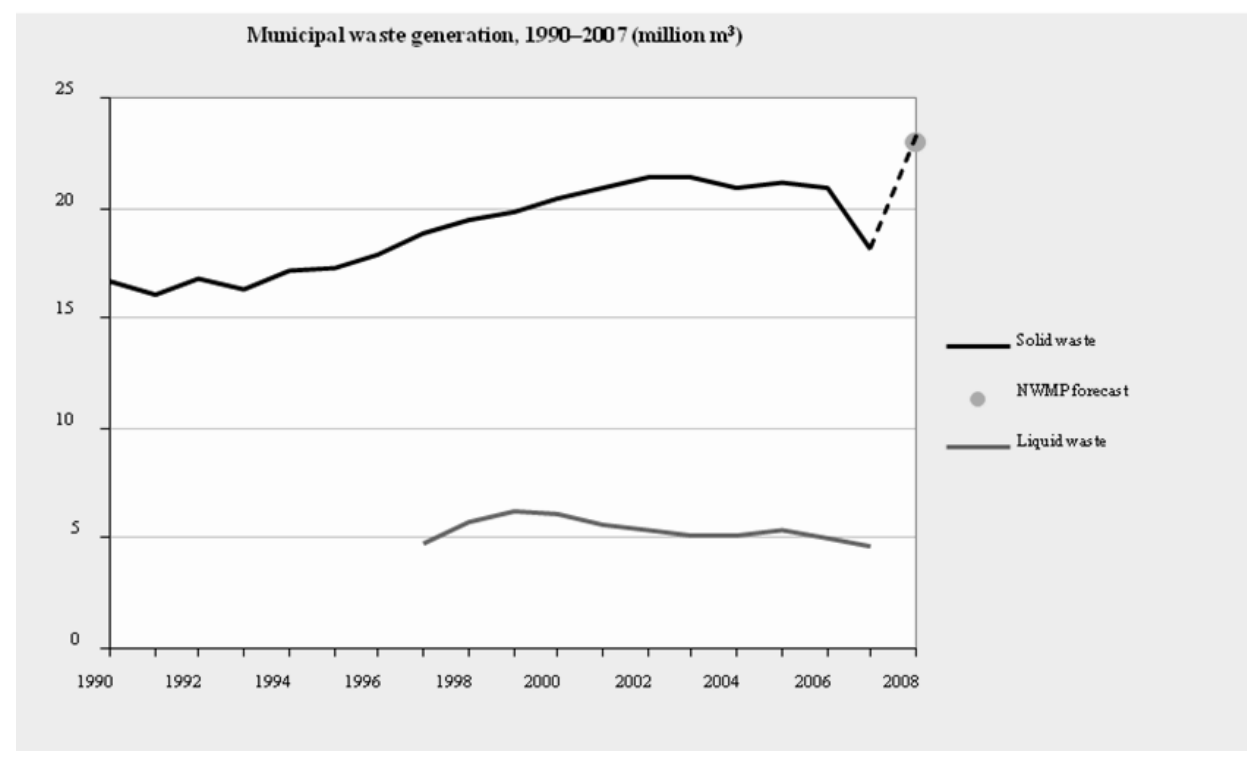

Figure 5. Municipal waste

Source: Pomázi--Szabó (2008a).

sons. The impact of industrial restructuring has resulted in an identically significant decrease in the counties of Komárom-Esztergom and Györ-Moson-Sopron. Obsolete and outdated technologies were replaced with new manufacturing plants. In contrast, the amount of hazardous waste has largely increased in Hajdú-Bihar County with the expansion of the pharmaceutical works. Out of all the counties, it is Veszprém, with its outdated industry, that was responsible for the largest amount of hazardous waste after 2006. Hazardous waste produced in 1997 barely reached $23 \%$ of the 1990 levels.

In Hungary, only the nuclear power station at Paks uses nuclear fuel for electricity generation. Annually 58.6 tons of spent nuclear fuel elements are produced here, along with approximately 100 cubic meters of solid and 250 cubic meters of liquid waste of low and intermediate levels of radioactivity. These hazardous waste materials are professionally treated (in hazardous waste incinerators, chemically safe waste dumps and temporary containers). In 1999, about 950 kilograms of chemicals per capita were produced in Hungary, one third of which was toxic. By 2006 the total quantity produced had increased by $15 \%$, while that of toxic chemicals had grown by one third. 


\section{Environmental Conflicts and Policy}

Attention was drawn to the most serious environmental conflicts in the period between 2000 and 2009 by campaigns led by environmental activists and organs of the mass media, as they ran counter to the interests of environmental protection, and this is something in which civil society has played a significant role. Among trans-boundary conflicts, the cyanide pollution of the Somes (Szamos) and Tisza rivers in Romania (by the gold mine in Baia Mare/Nagybánya) in January 2000 and the heavy metal pollution of the same rivers in March of the same year, this time within the territory of Hungary, count amongst the worst ecological disasters even to have taken place in Europe. According to measurements, some 105 to 110 tons of cyanide were released into the Somes (Szamos) and Tisza, and all living organisms were affected as a result. The estimated amount of fish stock lost reached 1,241 tons on the Hungarian sections of the two rivers.

A chronic conflict has remained outstanding for twenty years between Hungary and Slovakia over the issue of the hydroelectric power plant built at Gabčíkovo (Bös), and the withdrawal of Hungary from the project at Nagymaros, a settlement on the bend in the Danube river. The operation of the Slovakian nuclear power plant at Mochovce (Mohi) and illegal waste transportation and dumping has aroused further concern. Other issues include the illegal disposal of hazardous waste originating from Germany in the Kiskunság National Park, pollution of the River Rába (Raab) from Austria, the planning of a waste incinerator by an Austrian corporation near the Hungarian border at Heiligenkreuz (Rábakeresztúr) in Burgenland, and the opening of a gold mine in Roșia Montană (Verespatak) in Transylvania. The problems of environmental protection are further exacerbated by the large number of domestic issues, the solution of which is mainly the responsibility of the regional environmental authorities and local governments.

At present Hungarian environmental policy is based on the Environmental Act of 1995 and the 2nd National Environmental Program (NEP) for the period 2003-08, along with the 3rd NEP (2009-14), adopted by the Parliament at the end 2009. The Hungarian environmental policy planning gradually moved from the central planning system toward an integrated and participatory approach. The present political agenda is dominated by budgetary consolidation, short-term crisis management and economic convergence with the EU. The Hungarian National Sustainable Development Strategy, adopted by the Government in 2007, provides a long term vision for 2050. In 2008, two important institutions were established by Parliament to enhance the concept of sustainable development and environmental democracy: the National Sustainable Development Council and the Parliamentary Commissioner for Future Generations (acting as ombudsman). The National Sustainable Development Council was established by a resolution of the Parliament in May 2008. The Council represents a consultative and advisory body 
of the Parliament on matters relating to sustainable development (mainly at strategic planning and conceptual level). The original purpose was to create a broad, multi-stakeholder consultative platform that is detached from central Government. The Council is chaired by the Speaker of Parliament, 4 co-chairs delegated by: Government, Hungarian Academy of Sciences, parliamentary opposition and civil society. Council members, of which there are 32, are delegated by parliamentary parties, the Hungarian Academy of Sciences, Chambers of Commerce and Industry, Associations of local governments, churches, Alliance of Technology and Science Associations, Hungarian Conference of Rectors, Social and public health NGOs, Ethnic minority NGOs, Environmental NGOs, Generational NGOs, Education and Culture NGOs.

Legislative steps were taken in the early 2000 s to create a position of ombudsman of future generations. In 2006 and 2007 multiparty consultations were initiated on the introduction of the ombudsman for future generations, strongly supported by the President of the Republic. The ombudsman was elected by the Parliament for six years after three failed votes in summer 2008 (the election requiring a two-third majority). The ombudsman has the right to investigate the implementation of the constitutional right of citizens to a "healthy environment" in a general manner (policy making, legislation) and in specific cases (individual complaints). He/she can intervene and suspend the execution of administrative decisions if they may lead to irreversible damage, and he/she can call on any person or organization to stop polluting illegally.

The Organisation for Economic Co-operation and Development (OECD) has carried out and published for the second time a comprehensive assessment of Hungarian environmental performance (OECD 2008). Over the period between 2000 and 2008 Hungary's economy continued to grow and the population continued to decline and age. The country underwent further structural changes and integration into the European economy. Hungary acceded to the European Union in May 2004. Imports and exports of goods and services represent $78 \%$ of GDP, and more than $85 \%$ of the GDP is generated in the private sector. The country has received foreign direct investment reaching 5.4\% in 2006. Fiscal consolidation and economic convergence in the EU now dominate the policy agenda.

In addition to the environmental progress between 1990 and 2000, the period also bore witness to consolidation of this progress and alignment with EU environmental acquis communautaire (a legal term used in the EU to refer to the total body of EU law passed thus far). But pollution, energy and resource intensities can still be improved and environmentally related health problems subsist. Overall, the road towards environmental convergence within the EU will be a long one, and only one of a number of issues (OECD, 2008). To meet these challenges, Hungary will need to strengthen its environmental efforts in infrastructure building (e.g., for waste and wastewater treatment) and implementation of environ- 
mental policies, further integrate environmental concerns into economic decisions, and reinforce international cooperation on environmental issues.

Hungary has developed a comprehensive environmental planning framework, included two National Environmental Programs (for the periods between 1997 and 2002 and 2003 and 2008) and related thematic action programs, with quantitative objectives and performance indicators. Its programming framework formed the basis for the Environment and Energy Operative Program, which specifies the use of EU Funds and Hungarian matching funds for the period between 2007 and 2013 in the context of the National Development Plan. The review period was characterized by the consolidation of environmental legislation, mostly driven by EU environmental acquis communautaire and EU membership in May 2004. Three of the four transitional periods granted to Hungary have already expired, leaving only the one for the treatment of urban wastewater, which will last until 2015. Hungary is now also contributing to shape EU environmental policy (e.g., flood management, mining waste, chemicals, ground and bathing waters). The institutional framework for environmental management has evolved over the review period, with the gradual merger of authorities in charge of nature conservation, environmental protection and water quality and quantity management. As recommended in the first OECD review published in 2000 (OECD, 2000), enforcement activities have increased. Inspectorates have acquired both licensing and enforcement responsibilities over all environmental issues and the system sanctions for non-compliance has been significantly strengthened. Progress has been made towards the polluter pays principle and the user pays principle: the use of economic instruments has increased with the introduction of an "environmental load charge", applied to air emissions and wastewater discharges, and the revision of product charges on packaging wastes. Hungarian firms have greatly expanded their use of environmental management systems. Eco-labeling and green public procurement have also been promoted.

However, Hungarian environmental performance is still not fully in line with OECD-Europe standards and EU targets. In particular, some positive trends of the 1990s have slowed down in recent years (e.g., energy intensity, some air pollutant emissions, waste generation) or even reversed (e.g., the use of fertilizers and pesticides). Some health indicators are also of concern. Implementation of the second National Environmental Program (2003-08) has been lagging, and Hungary appears unlikely to reach its targets in a number of fields (e.g., water quality, waste recovery) (OECD, 2008). This suggests that efforts or available resources have not been always appropriate to implement the new environmental legislation, despite important EU support. The level of PAC (pollution abatement cost) investment expenditure is the same as in the first OECD review (about $1 \%$ of GDP), and total PAC expenditure is about $1.6 \%$ of GDP. Over the review period, financial and human resource shortage has limited monitoring and enforcement capacity of 
inspectorates. Regional and municipal administrations need to strengthen their environmental capacities and their expertise in economic analysis, also with a view to better absorbing EU funds for environmental projects. The effectiveness of economic instruments must be regularly assessed and charges periodically adjusted in order to provide a balanced mix of licensing regulations and economic incentives. Social affordability issues also need to be considered, in particular the interests of the poor.

\section{Urban Sustainability: Case Study of Budapest}

The phenomenon of social metabolism and its territorial presence in the cities of OECD and non-OECD countries was analyzed by Pomázi and Szabó (Pomázi-Szabó, 2006) in detail. The examination of urban metabolism requires a multidisciplinary approach, since cities as ecosystems represent complex and comprehensive systems of social, economic and environmental processes. The concept of urban metabolism can help further an understanding of the sustainable development of cities by drawing analogies with the metabolic processes of living organisms. One can discern numerous similarities between the metabolisms of biological organisms and those of cities. Cities transform incoming raw materials, fuels, food and water into the built environment, human biomass, and residuals (Decker et al., 2000). The analysis of urban metabolism practically means the quantitative exploration of inputs and outputs of energy, water, nutrients, raw materials, and wastes.

Urban metabolism can be defined as the complex total of technical, social and economic processes of cities, manifested in growth, energy production and neutralization of refuse. Until now, only a few studies were devoted to the calculation of energy flows in cities. Researchers tended to focus rather on nutrients, raw materials and the hydrological cycle. Urban metabolism is worth studying from different perspectives. First, the exploitation of resources and waste generated can be accurately measured by the features of metabolism; these can be also used as sustainability indicators. Second, the analysis of urban metabolism makes it possible to measure resource efficiency and explore cyclical flows of resources. In addition, this provides a good analytical framework for an account of urban stocks and throughputs and for a better understanding of critical processes (increasing or decreasing ground water resources, heat islands, long term impacts of hazardous construction materials, etc.).

Several factors influence urban metabolism. The urban structure, which included population density and morphology and transport technology, can influence energy and material flow. In the case of cities with large areas and low population densities per capita, the energy intensity of transport is much higher in com- 
parison with a compact city. Climate also has a great impact on urban metabolism, since heating energy demand is much bigger in a winter under continental climate than in a mediterranean city. The technology in use, the share of vegetation, energy prices, and the age and quality of the buildings also influence the energy use of cities.

The city studies generally show that metabolism is increasing. This is natural in absolute terms, when the population of cities is also growing. At the same time the per capita values are increasing, too. An American engineer, Abel Wolman, regarded as the father of urban metabolism, described the phenomenon of urban metabolism with reference to the example of a hypothetical city of 1,000,000 inhabitants (Wolman, 1965). According to Wolman, "The metabolism of a city can be defined as all the materials and commodities needed to sustain the city's inhabitants at home, at work and at play". One of Wolman's later followers, Thomas Graedel, defined cities as living organisms: "Cities can be regarded as organisms, and analyzed as such, in an attempt to improve their current environmental performance and long-term sustainability" (Graedel, 1999).

\section{Main Features of Budapest}

Hungary's capital, Budapest, together with its surroundings, represents a highly developed metropolitan region in Central Europe where the technical and economic advances have made it possible to support some $2,500,000$ people ( $25 \%$ of the country's total population) on a land area of about 2,500 square kilometers. This population depends on a continuous supply of materials, energy and information in everyday function. Economic activities are highly concentrated in $\mathrm{Bu}-$ dapest, producing roughly $40 \%$ of the national Gross Domestic Product.

Budapest was originally created out of the unification of the settlements of Buda, Óbuda, and Pest in 1873. In the new era of construction (the second half of the 19th century), considerable construction was undertaken, including the construction of housing in the form of apartment blocks, bridges, modern forms of local transportation, streets (first cobblestone and later asphalt), new water and sewer systems, and later gas and electricity systems. In 1950 a change took place that was decisive from a governmental standpoint. On the first of the year, the surrounding cities and other settlements were connected to Budapest, and Greater Budapest came into existence, with 22 districts (currently 23) in place of the old 10 , later 14 . With the attachment of seven towns and 16 villages to the former $\mathrm{Bu}-$ dapest, its area enlarged from 207 square kilometers to 525 square kilometers (an increase of $154 \%$ ), the number of its inhabitants increased from $1,050,000$ to 1,600,000 (an increase of 52\%), and the number of its districts grew from 14 to 22 (an increase of 57\%). Thus it became the seventh metropolis of Europe of its time. 
In 2007, the main social, economic and environmental indicators of Budapest were as follows:

Total population: $1,700,000$ million;

Population density: 3,238 per square kilometer; GDP: $40 \%$ of the country's total GDP;

Passenger cars: 35 per 100 capita;

Green areas: 9.9 square meters per capita;

Annual municipal waste generation: 630 kilograms per capita;

Annual $\mathrm{CO}_{2}$ emissions: 5.7 tons per capita.

\section{Main Economic, Social and Environmental Trends in Budapest}

The population of Greater Budapest increased from 1,600,000 in the early 1950 s to $2,060,000$ in 1980 . From 1980 onwards, the population has been dwindling due to the decreasing birth rate on the one hand, and migration to surrounding settlements (suburbanization) on the other. In 2006, the population dropped to $82.5 \%$ of its level of 1980 . While $19.2 \%$ of the country's total population lived in the capital in 1980 , only $16.8 \%$ of the population of Hungary counted as residents of Budapest in 2006. During this time period, the housing also changed significantly. According to official statistics, there were 536 thousand dwellings in 1960. This number has been increasing continuously, although the pace of the construction of panel blocks of flats begun in the 1960s $(1.6 \%$ average increase per year) slowed to an annual 0.5\% after 1990. Between 1960 and 1990, housing construction took place at a pace that the city had never experienced before.

This increase was characterized by the fact that the city's population per dwelling was 3.3 capita in 1960, while it was less than two capita in 2006. It is also significant that one in five dwellings built in the country during the 1980s was located in Budapest. Panel blocks of flats were planned to last some 30 to 70 years, so the first ones are approaching the end of their life span and require complete renovation or even demolition. In recognition of this situation, one can expect the demolition waste stream to increase significantly in the coming decades (PomáziSzabó, 2008b).

Ownership and use of passenger cars expanded from 39,000 in 1965 to 596,000 in 2005, an increase of fifteen-fold. However, as a per capita figure, ownership of passenger cars still hardly exceeds half of the OECD average (35 versus 52). During these four decades, there was a roughly $350 \%$ enlargement in the amount of buses, while use of trucks increased by almost three-fold. During the half century covered by the research, inventories of durable goods including refrigerators, washing machines, televisions, etc., grew considerably, and major 
transformations occurred in their structure. Since elements of these appliances sooner or later will emerge on the output side of material flows as waste streams and can cause serious environmental consequences, their investigation is indispensable for mapping the overall picture of material flows. However, a detailed analysis of household statistics is required in order to understand the process in depth. According to the data of 2005, the per capita municipal solid waste generation was about 630 kilograms compared with the national average of 460 kilograms and the OECD average of 560 kilograms.

Data for 2005 indicate that hardly half of the population of Budapest was connected to wastewater treatment plants. At the same time, this figure barely approached $35 \%$ at the national level, while the OECD average was about $70 \%$. However, a significant increase is probable in the share of the population connected to wastewater treatment plants (WWTP) if a new wastewater treatment plant now under construction, with high purification capacity, is installed.

As far as the emissions of air pollutants are concerned, both Budapest and country data are below, sometimes well below, the OECD average in the case of sulfur dioxide, nitrogen oxides and carbon dioxide. The gap is very significant for sulfur dioxide. While the national average is near the OECD average, per capita emissions of Budapest are one fifth and one sixth of their values, respectively. In the case of nitrogen oxides and carbon dioxide due to transport volume and concentration, the emissions of the capital exceed the national levels. However, they are only about half of the OECD average.

\section{Evolution of Urban Metabolism in Historical Perspective for 1955-2005}

In the longitudinal investigation of the urban metabolism of Budapest the following components were used on the input side: total water consumption, total (natural) gas consumption, total electricity consumption, total quantity of heat, and food consumption. On the output side of urban metabolism data concerning the following components were available for longer periods of time: total wastewater, total municipal solid waste collected, and emissions of air pollutants $\left(\mathrm{CO}_{2}, \mathrm{SO}_{2}, \mathrm{NO}_{\mathrm{x}}, \mathrm{CO}\right.$ and particulate matter). On the basis of the study of the total resource use of Budapest covering half a century, three main periods could be distinguished. Concerning the input side of resource efficiency, the first period lasted from 1955 to 1980, which can be considered as the extensive socialist development phase of the metropolis. In this era, energy and water use, as well as food consumption, increased at a significant pace. The next shorter period between 1980 and 1990 can be regarded as a pre-transition period, characterized by temporary stagnation of resource use. The third period, which began in 1990, is distinguished by a robust improvement in resource efficiency (Pomázi-Szabó, 2008b). 
This development of resource productivity can be explained by the notable decrease of the population, the transformation of the consumption patterns of the city, and a more consequent application of the "user pays" principle. The latter convincingly shows, for example, that water fees increased by $250 \%$ over the course of the last decade, and as a consequence, the consumption habits of households altered rapidly (water consumption decreased by about one fourth). Considering the output side of resource efficiency, a five-year shift can be discerned, compared with the input side. The output side can be divided into the following periods: the first (extensive period) lasted from 1955 to 1975; the second, the era of stagnation or pre-transition period, was between 1975 and 1985, while the third period (the transition period) is still going on, although not so "spectacularly" as in the case of the input side.

The annual quantity of collected municipal solid waste increased by more than $500 \%$ (from 120 to 630 kilograms per capita) between 1955 and 2005. This trend unambiguously shows the specific features of the "throw away" consumption society of Budapest. The change in the composition of waste between 1990 and 2005 illustrates the previously mentioned alteration of consumption patterns. At the beginning of the 1990 s the share of plastics in waste was about $5 \%$, however, it has been significantly increasing since 1997, and its share approached $17 \%$ in 2005 (Pomázi-Szabó, 2008b).

One of the major measuring tools of urban metabolism is the monitoring of waste flows and the diversion of waste streams from final disposal and incineration, namely the prevention and reduction of waste generation, as well as the reuse of waste. "3R" policies (reduce, reuse, and recycle) initiated by Japan and confirmed at several G8 summits can be used at the city level as well, and should be regarded as an important part of sustainable city planning (Namiki, 2008).

\section{Resource-related Targets of the Budapest Environmental Program of 2008-13}

In 2007, the Budapest City Council adopted the Budapest Environmental Program for the period between 2008 and 2013. It includes several measures aiming at a more efficient use of natural resources. In the field of energy management, the target was set to reduce total energy consumption of Budapest by $10 \%$ by 2013 . To this end, the insulation of buildings as well as individual heat metering of blocks of flats and regulation of heating systems will be continued. A 10\% reduction should also be reached in energy consumption of the city-owned public institutions. The share of the use of renewable energy sources will reach 5\% in total energy consumption. 
Green areas play a very important role in the life of a metropolis, since they can reduce significantly the risk of the emergence of a city heat island, for example. According to the Budapest Environmental Program, green area coverage will be maintained at its 2005 level, and the per capita figure will exceed the 2005 level (6.2 square meters). The indicative target to reduce per capita solid municipal waste generation is 540 kilograms and 500 kilograms by 2013 and 2020, respectively (it was 580 kilograms in 2006). The share of selective waste collection should be improved by another $5 \%$, while that of biologically degradable organic waste should be increased from $4 \%$ to $25 \%$ and that of packaging waste from $50 \%$ to $60 \%$ by 2013 .

Unfortunately, the Budapest Environmental Program does not set up indicative targets for wastewater treatment, although it is one of the most significant environmental problems in the capital of Hungary. In Budapest, untreated wastewater represents a high proportion (only $51 \%$ of the wastewater is treated biologically), and almost half of the wastewater is canalized directly into the Danube as a major sink.

\section{Conclusions}

Since the change of regimes in Central Europe, numerous significant changes have been made in the context of furthering sustainable development, both on the level of policy and in means and consistency of implementation. Integration into the EU has been one of the driving forces of change, but has brought with it additional challenges on the local, national, and international levels. Maintaining balance between environmental measures and the perceived needs of local populations in the midst of global economic crisis will remain a significant challenge, but carefully tailored policies and several successes of the recent past offer reason for cautious optimism.

\section{References}

Archibald, S. and Bochniarz, Z. (2008) 'Assessing Sustainability of Transition in Central European Countries. A Comparative Analysis' in Z. Bochniarz and G. B. Cohen (eds.) The Environment and Sustainable Development in the New Central Europe (New York-Oxford: Berghahn Books) 19-44.

Bochniarz, Z. and Cohen, G. B. (eds.) [2008]: The Environment and Sustainable Development in the New Central Europe (New York-Oxford: Berghahn Books) 260.

Decker, H., Elliott, S., Smith, F. A., Blake, D. R. and Sherwood Rowland, F. (2000) 'Energy and Material Flow through the Urban Ecosystem' Annual Review of Energy and the Environment, Vol. 25, 685-740.

European Commission (2009) Five Years of an Enlarged EU. Economic Achievements and Challenges (Brussels: European Economy 1/2009). 
European Commission (2009) Communication from the Commission to the European Council. A European Economic Recovery Plan. (Brussels, 26.11. 2008, COM (2008) 800 final).

European Environment Agency (2007) Europe's Environment. The Fourth Assessment (Copenhagen: EEA) 452.

Graedel, T. E. (1999) 'Industrial Ecology and the Ecocity' The Bridge. Vol. 29, No. 4, 10-14.

Hungarian Central Statistical Office (HCSO) (1955-2006) Budapest Statistical Yearbooks, 1955-2006 (Budapest).

Hungarian Central Statistical Office (HCSO) (1955-2006) Public Utilities, 1955-2006 (Budapest).

Hungarian Central Statistical Office (HCSO) (1955-2007) Yearbooks of Hungary, 1955-2007 (Budapest).

Hungarian Central Statistical Office (HCSO) (1996-2005) Environmental Statistical Yearbook of Hungary, 1996-2005 (Budapest).

Hungarian Central Statistical Office (HCSO) (2008) A fenntartható fejlödés indikátorai Magyarországon (Sustainable development indicators in Hungary) (Budapest).

Ministry of Environment and Water (2004) National Environmental Programme 2003-2008 (Budapest).

Ministry of Environment and Water (2009) National Environmental Programme 2009-2014 (Budapest) (draft in Hungarian)

Namiki, M. (2008) Promotion of Sound Material Material-Cycle Society in Japan and 3R Initiative. Paper presented at the OECD-UNEP Conference on Resource Efficiency. Paris, 23-25 April 2008.

Organisation for Economic Co-operation and Development (OECD) (2000) Environmental Performance Reviews. Hungary (Paris: OECD).

Organisation for Economic Co-Operation and Development (OECD) (2008) Environmental Performance Reviews. Hungary (Paris: OECD).

Pomázi, I. and Szabó, E. (2006) A társadalmi metabolizmus (Social Metabolism) (Budapest: L'Harmattan).

Pomázi, I. and Szabó, E. (2008a) Magyarország környezeti vezérmutatói, 2007. (Headline Environmental Indicators of Hungary) (Budapest: UNEP GRID - Környezetvédelmi és Vízügyi Minisztérium (Ministry of Environment and Water)).

Pomázi, I. and Szabó, E. (2008b) 'Urban Resource Efficiency: The Case of Budapest' Hungarian Statistical Review, Special Number 12, 155-73.

Wolman, A. (1965) 'The Metabolism of Cities' Scientific American, Vol. 213, No. 3, 179-90.

The World Bank (2009) EU-10 Regular Economic Report. Main Report: Bottoming Out? (Washington, May) 61. 